\title{
Integrin inhibition promotes atypical anoikis in glioma cells
}

\author{
M Silginer ${ }^{1}$, M Weller ${ }^{1}$, U Ziegler ${ }^{2}$ and P Roth ${ }^{*, 1}$
}

Integrins regulate cellular adhesion and transmit signals important for cell survival, proliferation and motility. They are expressed by glioma cells and may contribute to their malignant phenotype. Integrin inhibition may therefore represent a promising therapeutic strategy. GL-261 and SMA-560 glioma cells grown under standard conditions uniformly detached and formed large cell clusters after integrin gene silencing or pharmacological inhibition using EMD-121974, a synthetic Arg-GlyAsp-motif peptide, or GLPG0187, a nonpeptidic integrin inhibitor. After $120 \mathrm{~h}$, the clusters induced by integrin inhibition decayed and cells died. In contrast, when cells were cultured under stem cell (sphere) conditions, no disaggregation became apparent upon integrin inhibition, and cell death was not observed. As poly-HEMA-mediated detachment had similar effects on cell viability as integrin inhibition, we postulated that cell death may result from detachment alone, which was confirmed using various permissive and nonpermissive substrates. No surrogate markers of apoptosis were detected and electron microscopy confirmed that necrosis represents the dominant morphology of detachment-induced cell death. In addition, integrin inhibition resulted in the induction of autophagy that represents a survival signal. When integrins were inhibited in nonsphere glioma cells, the TGF- $\beta$ pathway was strongly impaired, whereas no such effect was observed in glioma cells cultured under sphere conditions. Cell death induced by integrin inhibition was rescued by the addition of recombinant transforming growth factor- $\beta$ (TGF- $\beta$ ) and accelerated by exposure to the TGF- $\beta$ receptor inhibitor, SD-208. In summary, cell death following integrin inhibition is detachment mediated, represents an atypical form of anoikis involving necrosis as well as autophagy, and is modulated by TGF- $\beta$ pathway activity.

Cell Death and Disease (2014) 5, e1012; doi:10.1038/cddis.2013.543; published online 23 January 2014

Subject Category: Cancer

Integrins are a family of heterodimeric cell surface receptors formed by a combination of $18 \alpha$-subunits and $8 \beta$-subunits. ${ }^{1}$ Each subunit is a transmembrane protein with a large extracellular domain and a mostly short cytoplasmic domain, thus coordinating the assembly of cytoskeletal polymers and signaling complexes on the cytoplasmatic side of the cell membrane and an engagement of extracellular matrix (ECM) macromolecules or counter-receptors on the extracellular side. ${ }^{2}$ Integrins lack intrinsic catalytic activity, but by ECMintegrin interactions, signals are transduced into the cell through the activation of integrin-associated proteins and the establishment of focal adhesions. ${ }^{3,4}$ Ligated integrins can activate prosurvival pathways by several mechanisms such as the induction of the phosphatidylinositol 3-kinase (PI3K)/ AKT ${ }^{5} \mathrm{NF}-\kappa \mathrm{B}^{6}$ and RAS/RAF/MEK/ERK mitogen-activated protein kinase (MAPK) pathways, ${ }^{7}$ as well as the induction of BCL- $2^{8}$ and FADD-like IL-1 $\beta$-converting enzyme (FLICE)inhibitory protein (FLIP) expression, ${ }^{9}$ and reduction of p53 activity. ${ }^{10}$ In contrast, unligated integrins expressed on adherent cells or the antagonism of $\alpha \mathrm{v} \beta 3$ or $\beta 1$ integrins can induce apoptosis. ${ }^{3,11}$ Loss of ECM contact of adherent cells by disruption of integrin ligation promotes death by anoikis, and this form of cell death can be prevented by integrinmediated adhesion. ${ }^{10-12}$ Anoikis is deregulated in various pathological conditions and anchorage-independent growth is a hallmark of tumorigenic transformation of cells favoring metastasis. $^{10,13}$

The RGD integrins $\alpha \mathrm{v} \beta 3, \alpha 5 \beta 1$ and $\alpha \mathrm{v} \beta 6$ are frequently upregulated in several tumor types and associated with inferior outcome..$^{3,14}$ In gliomas, the expression of integrins $\alpha \mathrm{v} \beta 3, \alpha \mathrm{v} \beta 5$ and $\alpha \mathrm{v} \beta 8$ increases with the WHO grade of malignancy. ${ }^{15}$

A crosstalk between integrins and cytokines such as transforming growth factor- $\beta$ (TGF- $\beta$ ) is crucial for many aspects of tumor progression. ${ }^{3}$ TGF- $\beta$ is a multipotent cytokine with important effects on glioma cell proliferation, angiogenesis, invasion and immunity. ${ }^{16,17}$ Integrins have been attributed an important role in the activation of TGF- $\beta$

\footnotetext{
${ }^{1}$ Department of Neurology, Laboratory of Molecular Neuro-oncology, University Hospital Zurich, Zurich, Switzerland and ${ }^{2}$ Center for Microscopy and Image Analysis, University of Zurich, Zurich, Switzerland

*Corresponding author: P Roth, Department of Neurology, University Hospital Zurich, Frauenklinikstrasse 26, 8091 Zurich, Switzerland. Tel: +41 442555500 ; Fax: +41 44255 4507; E-mail: patrick.roth@usz.ch

Keywords: glioma; integrin; TGF- $\beta$; autophagy

Abbreviations: 3-MA, 3-methyladenine; AVO, acidic vesicular organelles; Cil, cilengitide; Col, collagen; crm-A, cytokine response modifier A; ECM, extracellular matrix; MDC, monodansylcadaverine; MFL, mega-Fas-ligand; Nec-1, necrostatin-1; NS, nonsphere; PI, propidium iodide; poly-HEMA, poly(2-hydroxyethyl methacrylate); pSmad2, phospho-Smad2; RAD, cyclo-(Arg-Ala-Asp-DPhe-Val); SC, sphere cell; Stauro, staurosporine; TEM, transmission electron microscopy; TGF- $\beta$, transforming growth factor- $\beta$; TMZ, temozolomide; zVAD-fmk, $N$-benzyloxycarbonyl-Val-Ala-Asp(O-Me) fluoromethyl ketone

Received 12.9.13; revised 29.11.13; accepted 02.12.13; Edited by A Stephanou
} 
by liberating active TGF- $\beta$ from the small latent complex (SLC). ${ }^{18}$ Moreover, $\alpha$ v integrins appear to control TGF- $\beta$ signaling in the human glioma and glioma-initiating cell lines at the transcriptional level as well. ${ }^{15}$ In turn, TGF- $\beta$ may promote glioma cell migration by the induction of $\alpha \mathrm{v} \beta 3$ integrin levels. ${ }^{19}$ Here, we characterized the mechanisms of cell death induced by integrin inhibition-mediated tumor cell detachment and its interaction with the TGF- $\beta$ pathway in mouse glioma models. Given the proposed link between sphere culture conditions and stemness in glioma and other cancer paradigms in vitro, ${ }^{20,21}$ most studies were performed in parallel under standard conditions and in sphere cultures.

\section{Results}

Integrin inhibition induces detachment and death of mouse glioma cells: rescue by sphere culture conditions. GL-261 and SMA-560 mouse glioma cells were cultured as adherent monolayer cultures under standard conditions or as sphere cultures. Adherent cells grown under standard conditions, referred to as nonsphere (NS) cells, detached after exposure to the integrin inhibitor cilengitide (Cil, EMD121974), but not after exposure to the control peptide RAD (cyclo-(Arg-Ala-Asp-DPhe-Val)), and formed large cell clusters (Figure 1a, top, Supplementary Figure 1). After $120 \mathrm{~h}$, the Cil-induced clusters disintegrated and there was widespread cell death confirmed by Trypan blue dye exclusion (data not shown). In contrast, no morphological effects were observed when sphere cells (SCs) were treated with Cil or RAD for up to $120 \mathrm{~h}$ (Figure 1a, bottom). The nonpeptidic integrin antagonist GLPG0187 induced detachment and the formation of large cell aggregates in GL-261 and SMA-560 NS cells too. Again, no morphological changes were observed in the SC cultures after exposure to GLPG0187 (Figure 1b). The $\alpha \mathrm{V}$ gene silencing confirmed that detachment and induction of cell death were a specific effect of integrin inhibition (Figure 1c).

The detachment of Cil-treated adherent cells was accompanied by a strong loss of metabolic activity as a surrogate marker of cell death in a time- and concentration-dependent manner as assessed by MTT assay. No such effect was observed in SC cultures (Figure 2a). This observation was not restricted to mouse cells as LN-18 human glioma cells, which were found to be most sensitive to detachment-induced cell death among a panel of human cell lines, ${ }^{22}$ also acquired resistance to Cil when maintained as sphere cultures (Figure 2a). Accordingly, GLPG0187 markedly reduced the viability of GL-261 NS and SMA-560 NS, but not of SC cultures (Figure 2b). Annexin V/propidium iodide (PI) staining confirmed the induction of cell death upon integrin inhibition. Cil-exposed NS cells displayed a high percentage of $\mathrm{PI}$ positive cells, whereas no changes were observed in SC cultures (Figure 2c). Similarly, exposure to GLPG0187 resulted in extensive cell death at concentrations as low as $1 \mathrm{nM}$ within $24 \mathrm{~h}$ in GL-261 NS cells and SMA-560 NS cells, but not in GL-261 SCs and SMA-560 SCs (Figure 2d). The assumption that integrin inhibition mediates cell death of mouse NS cells was further confirmed by the observation of reduced glioma cell viability at $24 \mathrm{~h}$ after siRNA-mediated $\alpha \mathrm{V}$ gene silencing (Figure 2e). Accordingly, NS glioma cells exposed to Cil lost membrane integrity as assessed by NHSbiotin staining (Supplementary Figure 2).

The induction of cell death by integrin inhibition is detachment mediated. There were no major differences in integrin mRNA levels between NS cells and SCs (Figure 3a). However, exposure to Cil reduced $\alpha \mathrm{v}$ mRNA expression in NS cells, whereas only minor changes were observed in SCs (Supplementary Figure 3A). Accordingly, Cil reduced $\alpha \mathrm{v}$ cell surface protein levels in NS cells, but not in GL-261 SCs, and only to a lower extent in SMA-560 SCs (Figure 3b). Similarly, intracellular $\alpha \mathrm{v}$ protein levels were affected by Cil mainly in NS cells (Supplementary Figure 3B). This lack of effect in the SC cultures also confirmed that preexposure to Cil did not interfere with recognition of $\alpha \mathrm{v}$ by the antibody used for flow cytometry.

The poly-HEMA-mediated detachment, which operates by hydrogel formation, had similar effects on cell viability as did the exposure to Cil (Figure 3c), consistent with the notion that the antiadhesive effect of integrin inhibition is responsible for cell death observed in NS cells. Conversely, poly-HEMA conditions expectedly had no effect on SC formation (data not shown). Accordingly, when GL-261 NS and SMA-560 NS cells were cultured on plates coated with collagens I or IV, which are not substrates for $\alpha \mathrm{v}$ integrins, Cil neither detached nor killed the cells (Figures $3 d$ and e).

Integrin inhibition-induced cell death in mouse NS is caspase independent. Neither increased caspase activity, assessed by DEVD-amc-cleavage (Figure 4a), nor increased caspase 3 processing on immunoblots (Figure 4b) was detected upon treatment with Cil. Furthermore, the pancaspase inhibitor zVAD-fmk ( $N$-benzyloxycarbonyl-Val-AlaAsp(O-Me) fluoromethyl ketone) inhibited cell death induced by mega-Fas-ligand (MFL) or Stauro (staurosporine) but not by $\mathrm{Cil}$ (Figure 4c). Similarly, when glioma cells were engineered to stably express the caspase $1 / 8$ inhibitor cytokine response modifier A (crm-A), MFL-induced caspase activity and cell death were blocked, but there was no rescue of integrin inhibition-mediated effects (Figure 4d, top). Finally, crm-A reduced the percentage of annexin $\mathrm{V}$-positive cells without increasing the overall number of doublenegative viable cells (Figure $4 \mathrm{~d}$, bottom), disclosing the exposure of annexin binding sites as being caspasedependent but epiphenomenal to cell death induction.

Integrin inhibitor-treated mouse glioma NS cells undergo necrosis. Next we investigated whether integrin inhibition induces autophagy in glioma cells. When SMA-560 NS cells were exposed to $50 \mu \mathrm{M}$ Cil, increased LC3A/B-II levels, which are associated with the induction of autophagy, were observed. Salinomycin was used as a positive control (Figure 5a). The administration of lower concentrations of Cil did not result in significant changes of LC3A/B-II protein levels. In GL-261 NS cells, higher constitutive LC3A/B-II levels were detected and no significant changes were observed upon Cil or salinomycin exposure (Figure 5a). Moreover, Cil induced the expression of the autophagyrelated protein beclin-1 in a concentration-dependent manner in GL-261 NS cells and even more in SMA-560 NS cells 
a

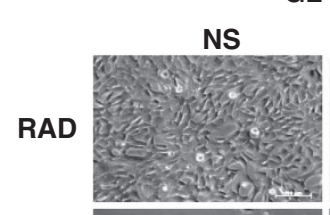

GL-261

SC

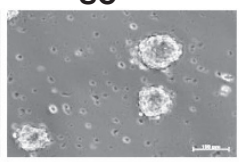

Cil
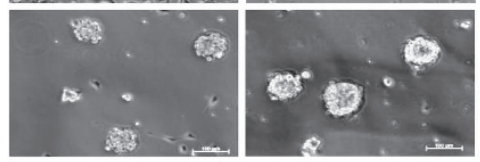

RAD

Cil
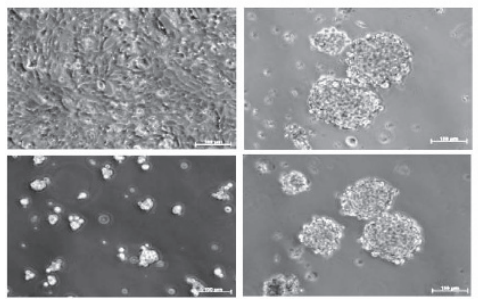

GL-261

b

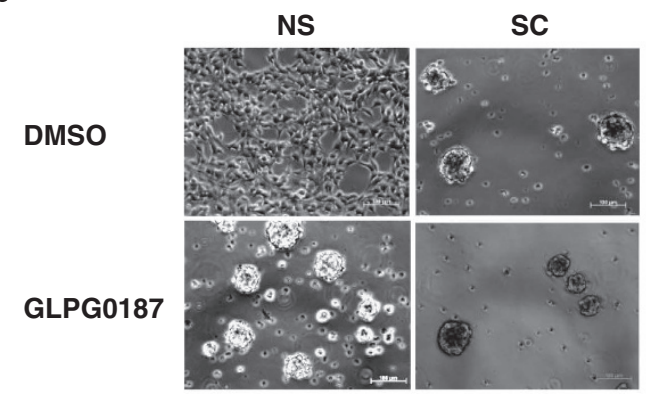

SMA-560
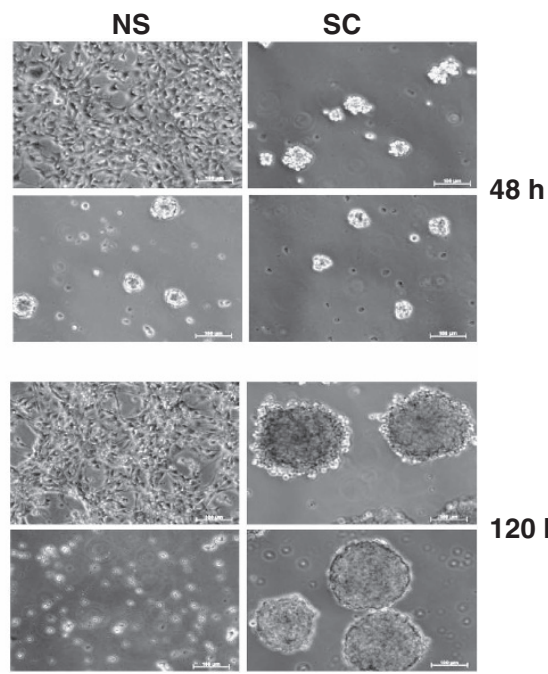

$120 \mathrm{~h}$

$48 \mathrm{~h}$

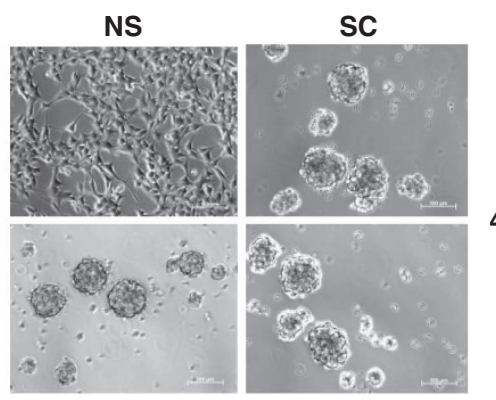

SMA-560

C
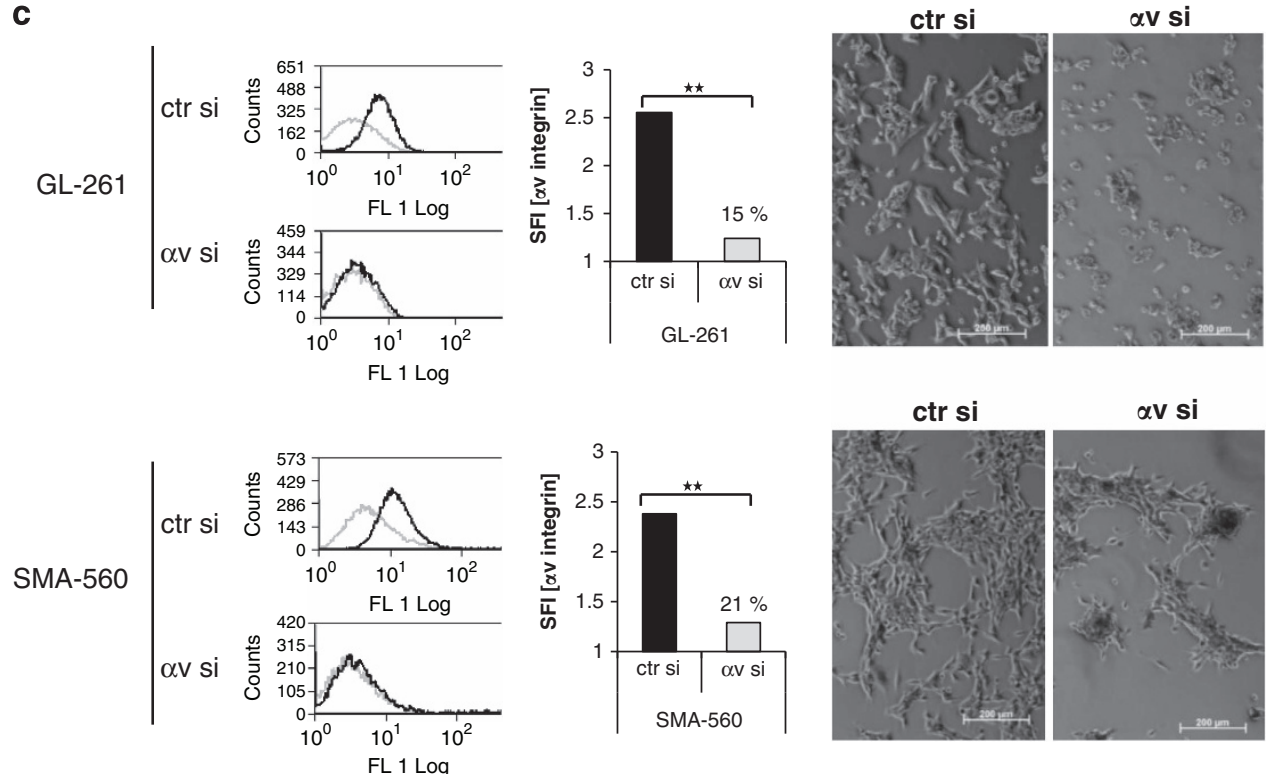

Figure 1 Integrin inhibition induces detachment of mouse NS cells. (a) GL-261 or SMA-560 cells cultured under standard (NS) or sphere (SC) conditions were seeded at 200000 cells/well, and after $24 \mathrm{~h}$ were exposed to control peptide (RAD) or cilengitide $(10 \mu \mathrm{M})$ (scale bar, $100 \mu \mathrm{m}$ ). (b) GL-261 (left) or SMA-560 (right) NS cells or SCs were exposed to DMSO control or GLPG0187 ( $1 \mathrm{nM}$ ) for $24 \mathrm{~h}$ (scale bar, $100 \mu \mathrm{m}$ ). (c) GL-261 NS cells (top) or SMA-560 NS cells (bottom) were transfected with control or $\alpha \mathrm{V}$ integrin siRNA. Gene silencing was quantified after $24 \mathrm{~h}$ by flow cytometry and is expressed as specific fluorescence index (SFl; left). The reduction of expression levels relative to control transfectants is indicated (middle). The transfected cells were monitored for attachment for $24 \mathrm{~h}$ (right, scale bar, $200 \mu \mathrm{m}$ ) 
a

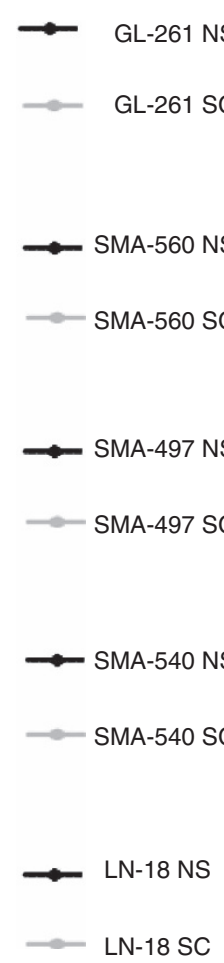

b

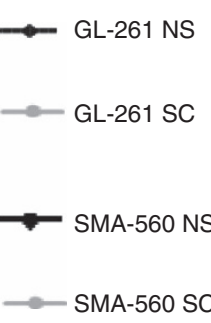

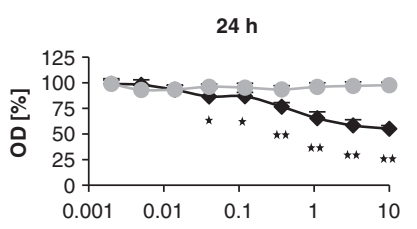
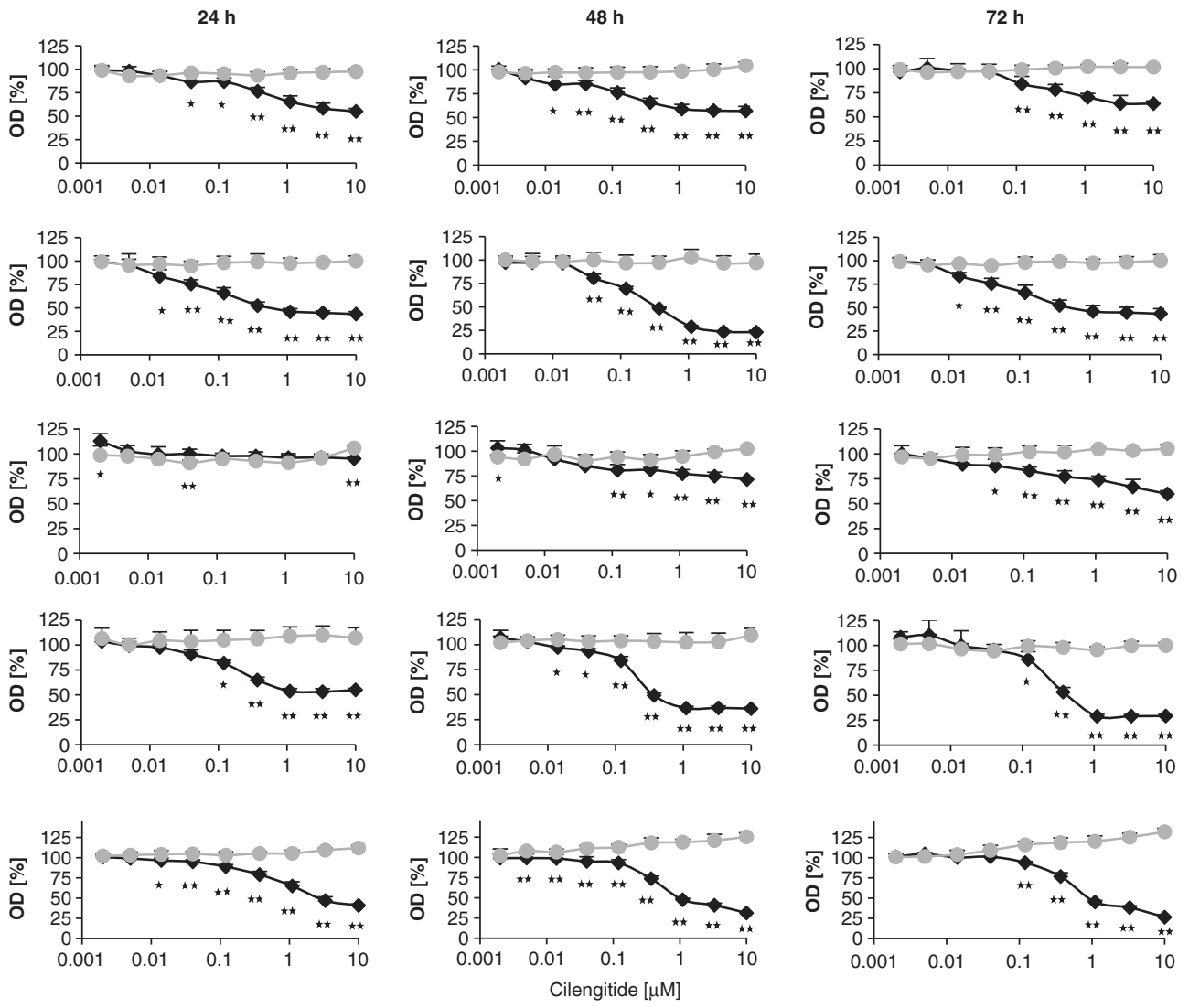
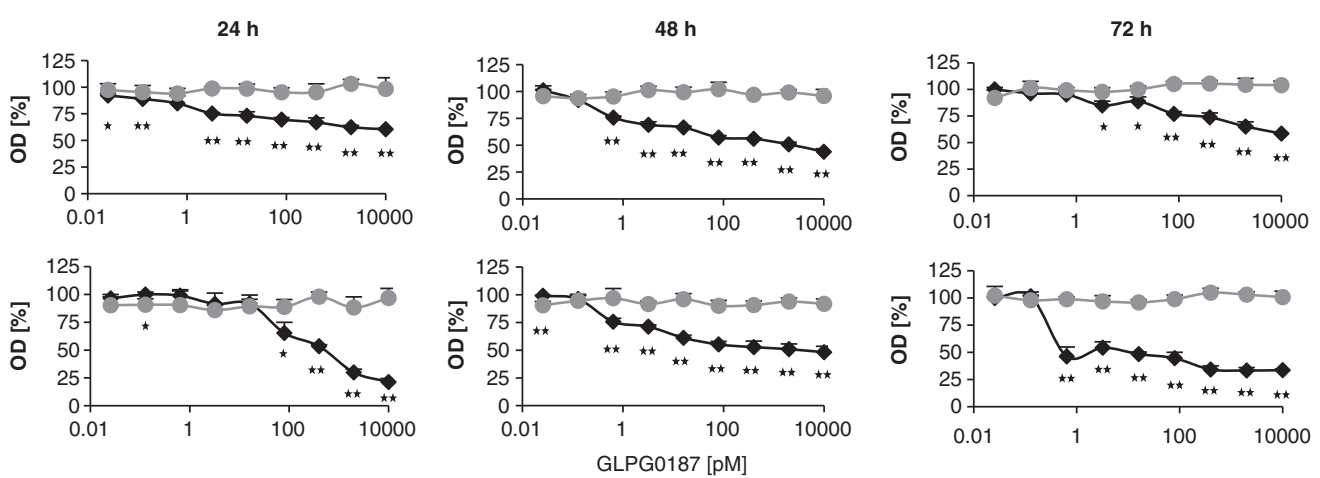

Figure 2 Sphere formation protects from cell death induced by $\alpha$ v integrin inhibition. (a) GL-261, SMA-560, SMA-497, SMA-540 or LN-18 glioma NS cells or SCs were exposed to RAD $(10 \mu \mathrm{M})$ or increasing concentrations of cilengitide as indicated for 24,48 or $72 \mathrm{~h}$. Metabolic activity was assessed by MTT assay and is indicated relative to RAD-treated cells. (b) GL-261 or SMA-560 NS cells or SCs were exposed to DMSO or to increasing concentrations of GLPG0187 as indicated for 24,48 or $72 \mathrm{~h}$. Metabolic activity was assessed by MTT assay and is indicated relative to control-treated cells. (c) SMA-560 or GL-261 NS cells or SCs were exposed to RAD or cilengitide (10 $\mu$ M) for $48 \mathrm{~h}$. Cell death was assessed by annexin V/PI staining. (d) SMA-560 and GL-261 NS cells or SCs were exposed to GLPG0187 (1 nM) or DMSO control for $48 \mathrm{~h}$ and analyzed for cell death by annexin V/PI staining. (e) GL-261 (top) and SMA-560 (bottom) control and $\alpha$ vnockdown transfectants were analyzed for cell death $24 \mathrm{~h}$ after transfection by annexin V/PI staining

(Figure 5b). To further analyze the relevance of autophagy in integrin inhibition-mediated cell death, GL-261 NS and SMA560 NS cells were stained with acridine orange for the detection of acidic vesicular organelles (AVOs) or with monodansylcadaverine (MDC) for the detection of autophagic vacuoles that are further hallmarks of autophagy. Compared with control cells, Cil-exposed NS cells of both cell lines showed increased AVO levels after $24 \mathrm{~h}$ even with Cil concentrations that did not induce LC3 A/B-II levels.
Moreover, salinomycin, as in the LC3 A/B-II studies, induced signs of autophagy only in SMA-560 cells (Figure 5c). Furthermore, compared with control cells, Cil-treated NS cells displayed an increase in MDC-positive vacuoles (Figure 5d). Next, we clarified whether autophagy is a survival signal or mediates Cil-induced cell death. To this end, glioma cells were cultured in the absence or presence of the autophagy inhibitor, 3-methyladenine (3-MA). When autophagy was blocked by 3-MA, the amount of dead cells 
C
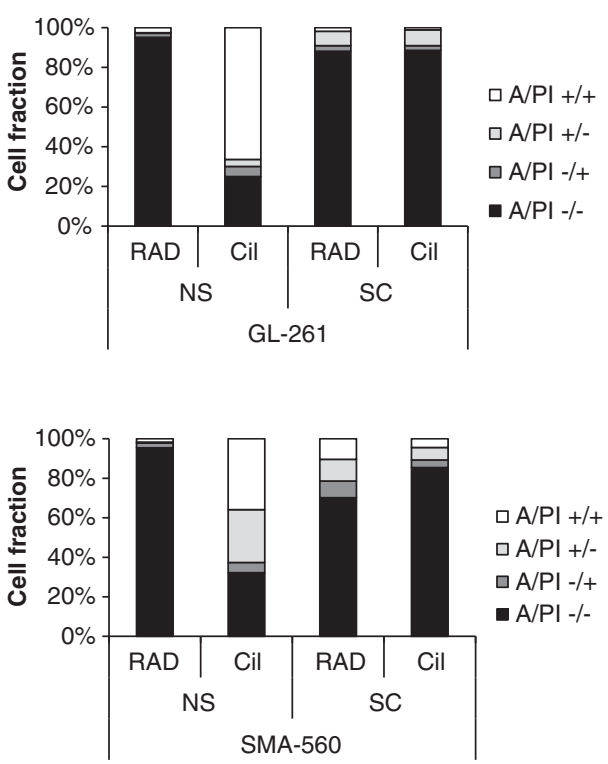

Figure 2 Continued d

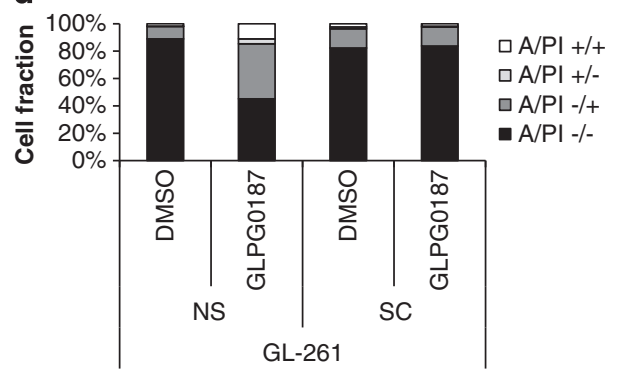

e
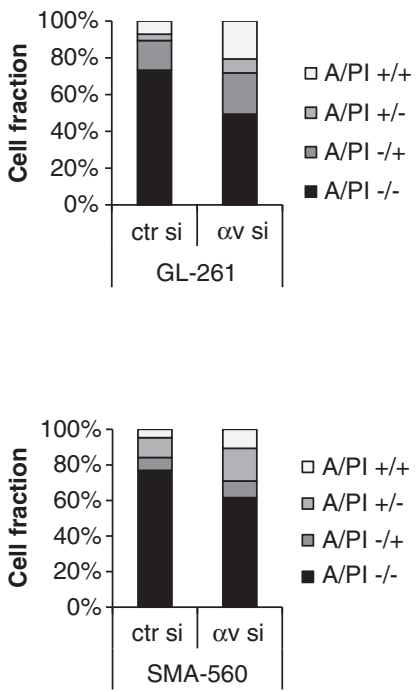

was increased, suggesting that autophagy in the context of integrin inhibition in murine NS cells represents a survival signal (Figure 5e).

Finally, we examined the morphology of integrin inhibitioninduced cell death using transmission electron microscopy (TEM). Cil-exposed SMA-560 NS cells were characterized by binding to each other, visible as dark adhesion sites along the cell membrane and necrosis-like cell debris between the cells, but no signs of apoptosis, such as crescent dark DNA along the nuclear membrane or dark cytoplasm, as those observed with Stauro, were noticed. Salinomycin-treated samples showed classical signs of autophagy such as mitochondria with swollen matrix, swollen endoplasmatic reticulum and an increased frequency of autophagosomes, characteristics that are not observed upon Cil exposure, indicating that cell death upon integrin inhibition in NS cells is essentially a necrotic process (Figure 6a). Indeed, SMA-560 SCs became apparent as a loose cell agglomeration with some dead cells inside the spheroid, but no major differences were observed between cells exposed to Cil or control peptide, and extensive cell death was noticed only as a result of Stauro treatment (Supplementary Figure 4). To distinguish necroptosis, the programmed form of necrosis, from the morphologically identical but unregulated form of necrosis, we blocked necroptosis with the receptor interacting protein (RIP)1 inhibitor necrostatin-1 (Nec-1). Exposure to $\mathrm{Nec}-1$ significantly attenuated the effect of Cil in murine GL-261 and SMA560 NS cells as well as in human LN-18 NS cells, indicating that necroptosis contributes to integrin inhibition-induced cell death (Figure 6b).

TGF- $\beta_{2}$ protects from cell death induced by integrin inhibition. We explored whether integrin inhibition also interferes with TGF- $\beta$ signaling in mouse glioma cells. ${ }^{15} \mathrm{Cil}$ reduced Smad2 phosphorylation in GL-261 NS cells and
SMA-560 NS cells, but not in SCs (Figure 7a). Similarly, exposure to GLPG0187 resulted in decreased phosphoSmad2 (pSmad2) levels in GL-261 NS cells and SMA-560 NS cells, but not in SC cultures (Figure 7b). To analyze whether these reductions of pSmad2 levels in NS cells result from detachment rather than from integrin inhibition, NS cells were again cultured on cell culture plates coated with collagen I to prevent detachment. Still, integrin inhibition resulted in reduced pSmad2 levels, although to a much lower extent, suggesting that impaired TGF- $\beta$ signaling results from both integrin inhibition and detachment in this model (Supplementary Figure 5). As integrin inhibition reduced pSmad2 levels only in GL-261 NS cells and SMA-560 NS cells, we asked whether reduced TGF- $\beta$ signaling was linked to integrin inhibition-induced detachment and cell death. Addition of exogenous recombinant TGF- $\beta_{2}$ to Cil-treated cells had no effect on detachment, and exposure to the TGF- $\beta$ receptor kinase inhibitor SD-208 did not induce detachment or cell death (data not shown). However, the addition of recombinant TGF- $\beta$ attenuated Cil-induced cell death in a concentration-dependent manner (Figures $7 \mathrm{c}$ and $\mathrm{d}$ ), and TGF- $\beta$-induced modulation of Cil-induced cell death was blocked by coexposure to SD-208 (Figure 7c). In fact, the extent of cell death was even more prominent when Cil-treated cells were coexposed to SD-208 (Figure 7e). Finally, we evaluated whether TGF- $\beta_{2}$ modulates integrin expression of GL-261 and SMA-560 NS cells. The $\alpha \mathrm{v}$ integrin levels were decreased by $\mathrm{Cil}$ and increased by exogenous TGF- $\beta_{2}$ in a concentration-dependent manner. No significant change was induced by SD-208 (Figure 7f). These results indicate that TGF- $\beta$-mediated upregulation of integrin expression may activate prosurvival pathways that may be involved in the counteraction of integrin inhibition-mediated cell death. To analyze whether TGF- $\beta_{2}$-mediated prevention is a specific effect in integrin inhibition-induced cell death, cells were 

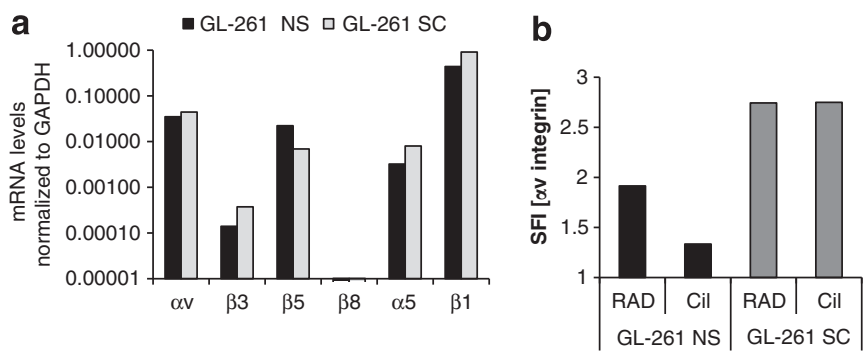

C
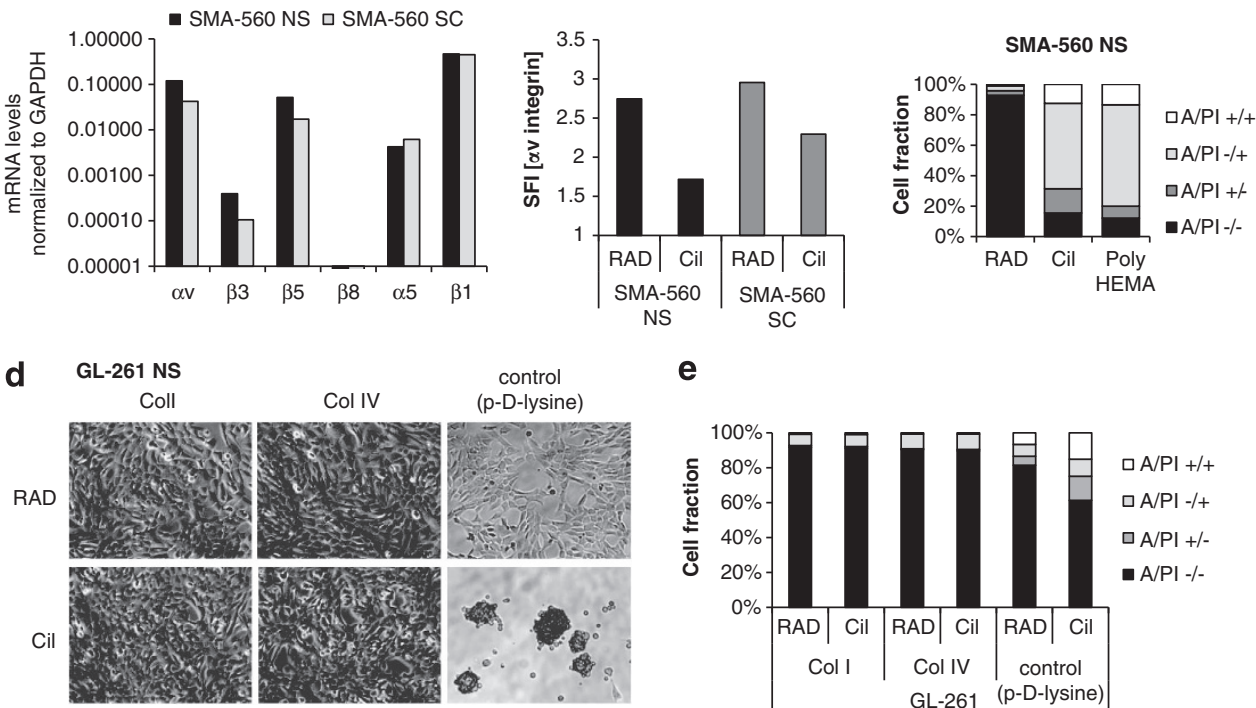

control NS

SC

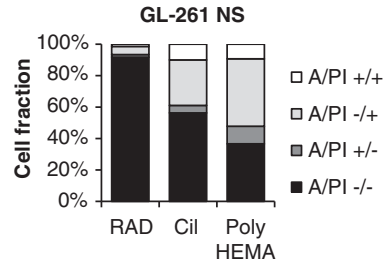

e
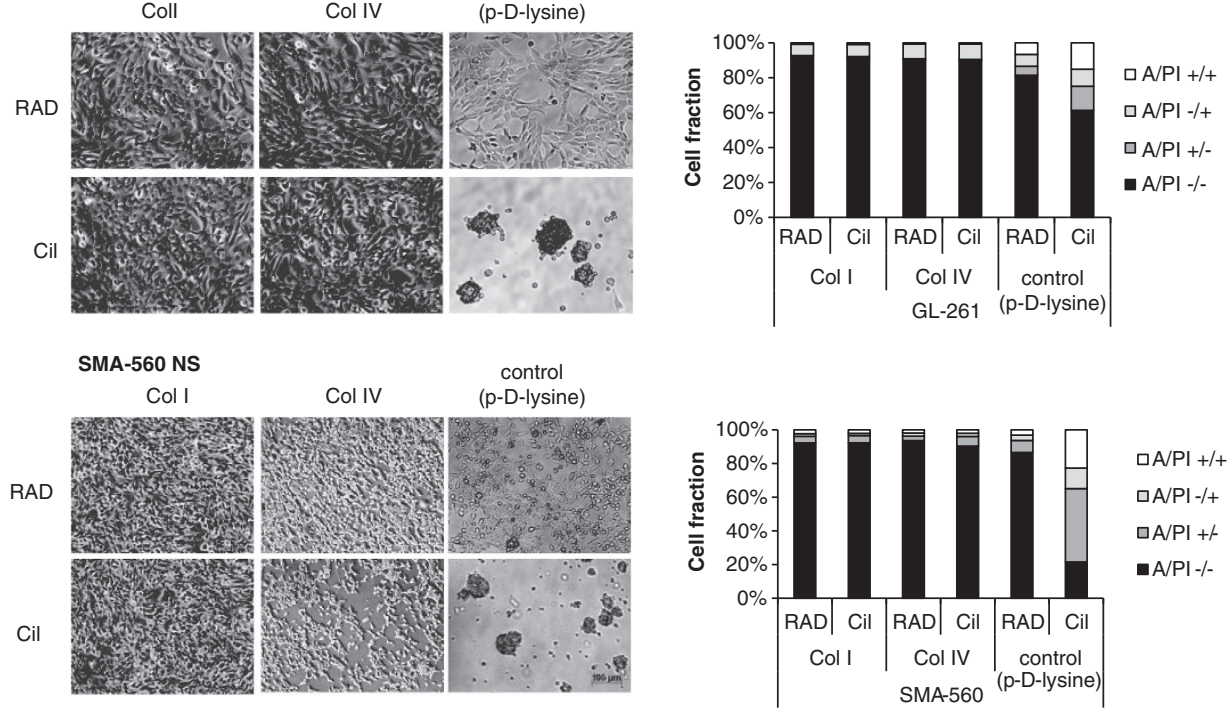

$\square \mathrm{A} / \mathrm{PI}+/+$ $\square \mathrm{A} / \mathrm{PI}-/+$ $\square \mathrm{A} / \mathrm{PI}+-$ -A/PI-/-

Figure 3 The induction of cell death caused by integrin inhibition is detachment mediated. (a) Integrin mRNA levels were assessed by real-time PCR in GL-261 or SMA560 NS cells or SCs. (b) The $\alpha$ v protein levels were assessed by flow cytometry in NS cells or SCs exposed to RAD or cilengitide (10 $\mu \mathrm{M}$ ) for $24 \mathrm{~h}$. (c) GL-261 NS cells or SMA560 NS cells were exposed to RAD or cilengitide $(10 \mu \mathrm{M})$ or cultured on cell culture dishes pretreated with poly-HEMA ( $12 \mathrm{mg} / \mathrm{ml})$ for $48 \mathrm{~h}$. Cell death was assessed by annexin V/PI staining. (d) GL-261 NS cells or SMA-560 NS cells cultured on plates coated with collagen I or collagen IV or poly-D-lysine (control) were allowed to attach for $24 \mathrm{~h}$. Subsequently, the cells were exposed to RAD or cilengitide $(10 \mu \mathrm{M})$ for $48 \mathrm{~h}$ and monitored for attachment (scale bar, $100 \mu \mathrm{m})$. (e) Viability of cells treated as in (d) was examined by annexin V/PI staining

exposed to a combination of increasing concentrations of Stauro, which induces apoptotic cell death, or to temozolomide (TMZ), an alkylating agent used for the treatment of glioblastoma patients, and TGF- $\beta_{2}$. Only very high concentrations of $T M Z$ were active in these assays and no rescue effect of TGF- $\beta_{2}$ was observed (Supplementary Figures 6 A and B).

\section{Discussion}

Integrins are crucial for many aspects of tumor biology including tumor initiation, progression and metastasis of solid tumors, making them an appealing target for cancer therapy. ${ }^{3}$ Various integrin antagonists have been developed for antitumor therapy and several of them are in late-stage clinical development, with all of them targeting RGD-binding integrins. ${ }^{23}$ Despite some clinical drawbacks in the development of pharmacological inhibitors, integrins remain a promising target for anticancer therapy owing to their action as regulators of various processes in tumor and tumor-associated host cells.

Inhibition of integrin signaling had variable effects on cell viability in glioma cells. ${ }^{22,24,25}$ In the mouse glioma model systems used here, we noticed extensive cell death following integrin inhibition in all four mouse glioma cell lines tested when cultured as adherent cells, that is, under standard conditions, whereas no such effect became apparent when the same cells were cultured under sphere conditions (Figure 1) that we had explored as a possible in vitro model 


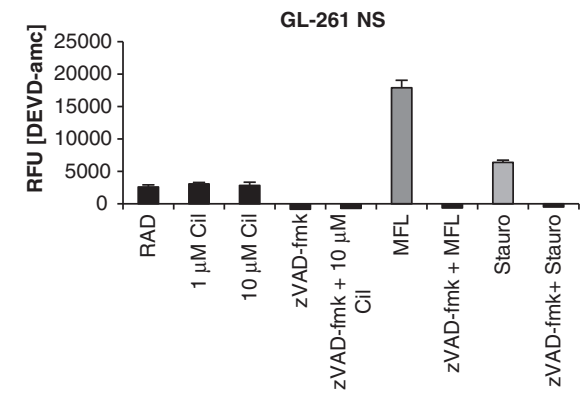

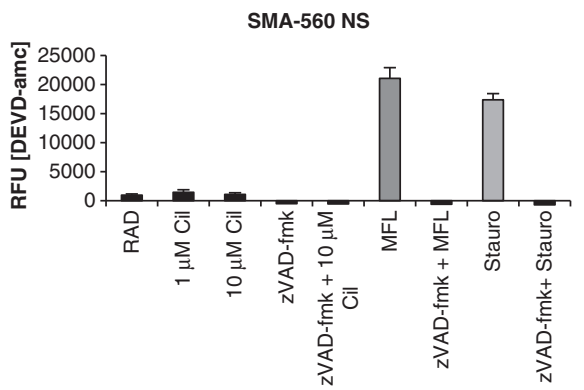

b

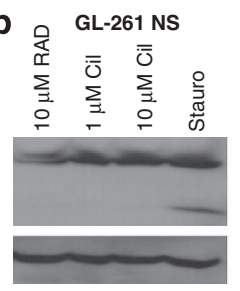

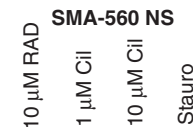
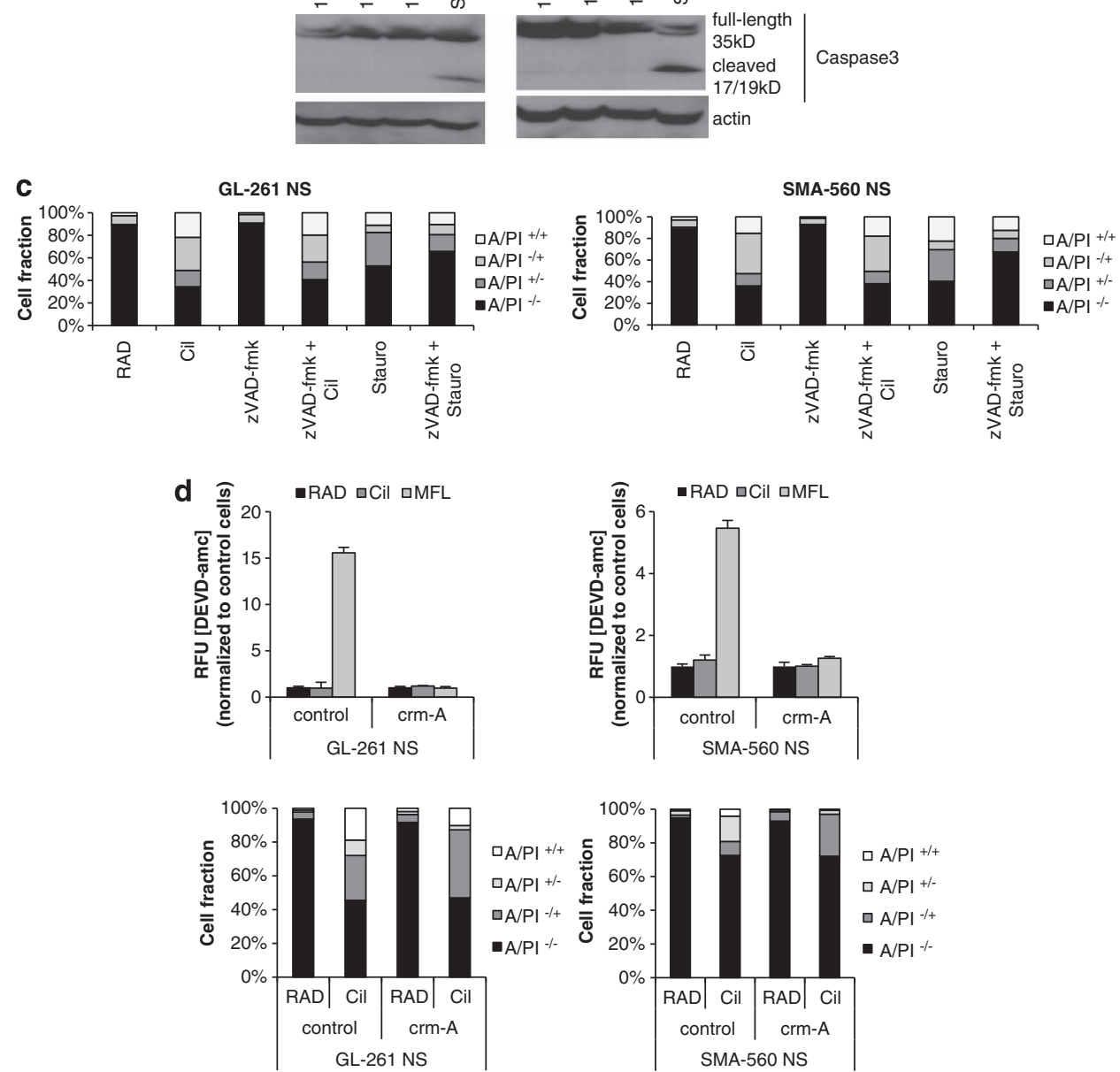

Figure 4 Integrin inhibition-induced cell death in mouse NS cells does not require caspase activity. (a) GL-261 NS cells (left) or SMA-560 NS cells (right) were exposed to $\mathrm{RAD}$, cilengitide $(1$ or $10 \mu \mathrm{M})$, MFL $(50 \mathrm{ng} / \mathrm{ml})$, staurosporine $(50 \mathrm{nM})$, zVAD-fmk $(10 \mu \mathrm{M})$ or to combinations thereof for $6 \mathrm{~h}$. DEVD-amc cleaving activity was determined fluorometrically. (b) Whole-cell protein lysates of GL-261 NS or SMA-560 NS exposed to RAD, cilengitide (1 or $10 \mu \mathrm{M})$ or staurosporine ( $50 \mathrm{nM})$ for $24 \mathrm{~h}$ were assessed for fulllength and cleaved caspase 3, using actin as a loading control. (c) GL-261 NS cells or SMA-560 NS cells were exposed to RAD, cilengitide (10 $\mu \mathrm{M})$, zVAD-fmk (1 $\mu \mathrm{M}$ ), staurosporine $(50 \mathrm{nM})$, or to a combination of ZVAD-fmk $(1 \mu \mathrm{M})$ and cilengitide $(10 \mu \mathrm{M})$ or staurosporine $(50 \mathrm{nM})$. Viability was assessed after $24 \mathrm{~h}$ of treatment by annexin V/PI staining. (d) Control or crm-A transfectants were exposed to RAD, cilengitide $(10 \mu \mathrm{M})$ or MFL ( $50 \mathrm{ng} / \mathrm{ml})$ for $6 \mathrm{~h}$ and analyzed for DEVD-amc-cleaving caspase activity (top). Cell death was assessed by annexin V/PI staining after exposure to RAD or cilengitide $(10 \mu \mathrm{M})$ for $24 \mathrm{~h}$ (bottom)

of stemness. ${ }^{26}$ Similarly, in human LN-18 glioma cells, integrin inhibition-induced cell death was only observed when the cells were cultured under standard adherent conditions, but not when cultured as spheres (Figure 2a). We confirmed that cell death triggered by blocking integrins is a consequence of detachment as integrin inhibition in cells maintained on collagen, which is not a ligand for $\alpha \mathrm{v}$ integrins, neither affected attachment nor viability (Figures $3 d$ and $e$ ).

Interestingly, the sphere culture controls that we included demonstrate that glioma cells may well survive in nonadherent culture systems and acquire a phenotype that induces nonresponsiveness to the signaling cascades of integrin-mediated 
a

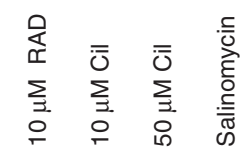

GL-261 NS

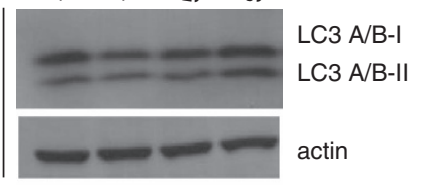

SMA-560 NS

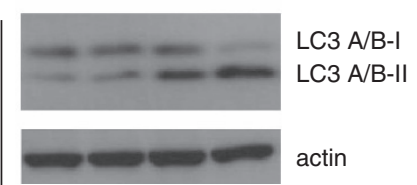

b
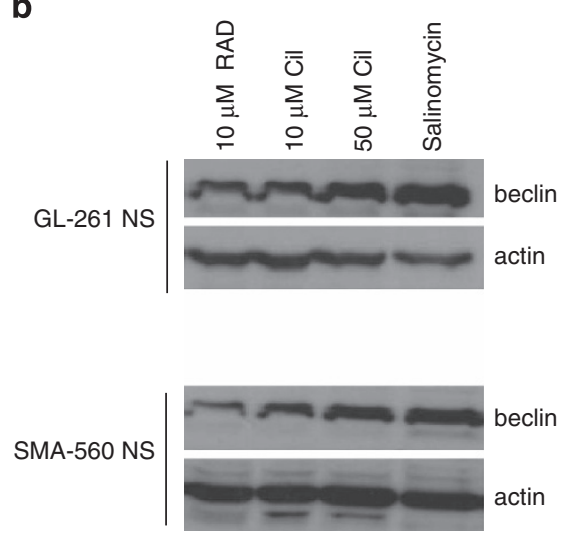

c

RAD
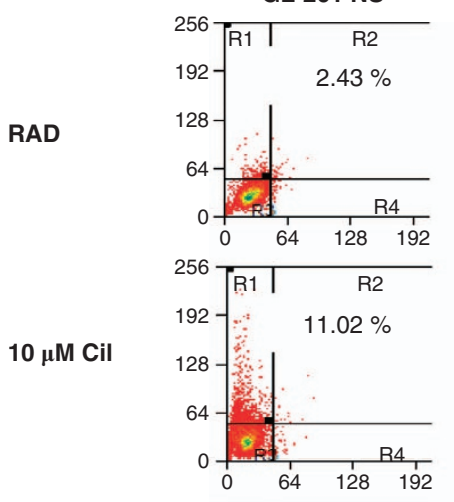

$50 \mu \mathrm{M}$ Cil

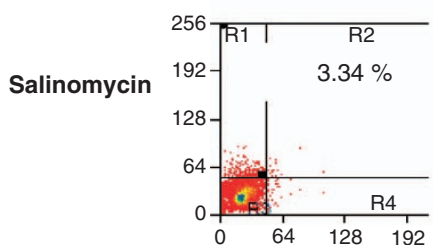

SMA-560 NS

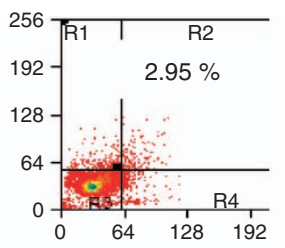

256 R1 । R2
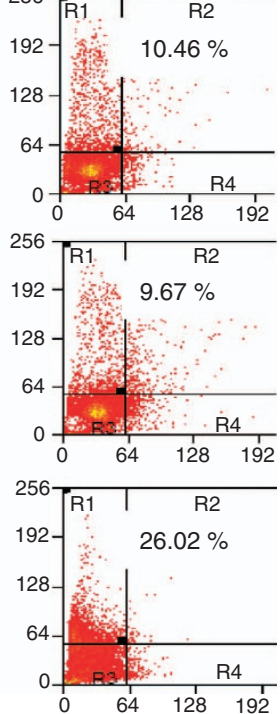

d

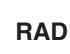

RAD

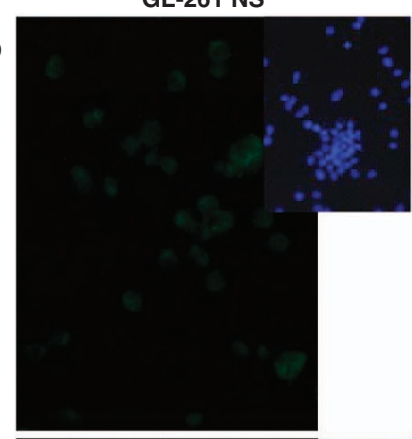

Cil

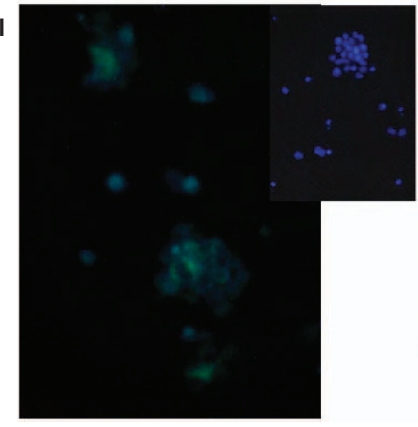

SMA-560 NS
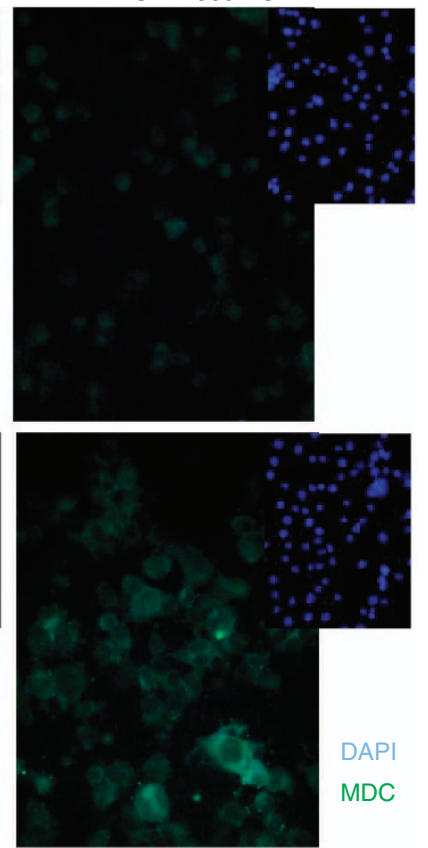
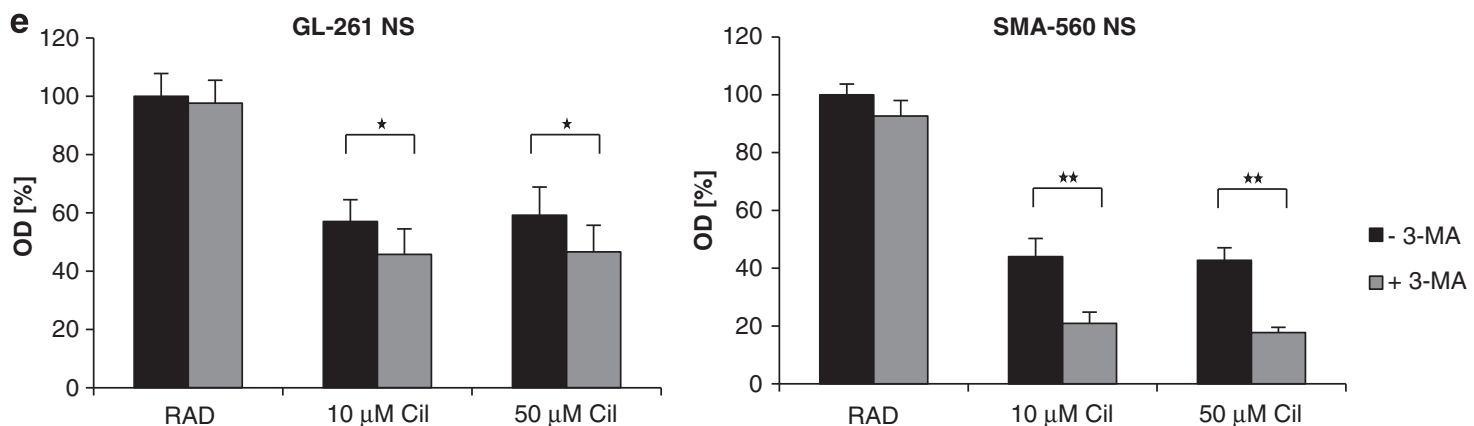

Figure 5 Cilengitide-treated mouse glioma NS cells show signs of autophagy. (a and $\mathbf{b}$ ) Whole-cell protein lysates of GL-261 NS cells and SMA-560 NS cells exposed to RAD, cilengitide $(10$ or $50 \mu \mathrm{M})$ or salinomycin $(4 \mu \mathrm{M})$ for $24 \mathrm{~h}$ were analyzed for LC3A/B (a) or beclin-1 (b) using actin as a loading control. (c) GL-261 or SMA-560 NS cells were exposed to RAD, cilengitide (10 or $50 \mu \mathrm{M}$ ) or salinomycin $(4 \mu \mathrm{M})$ for $24 \mathrm{~h}$. The development of AVOs was assessed by acridine orange staining. (d) GL-261 or SMA-560 NS cells were exposed to RAD or cilengitide $(10 \mu \mathrm{M})$ for $24 \mathrm{~h}$. Autophagic vacuoles were stained with MDC (green; nucleus, blue). (e) GL-261 or SMA-560 NS cells were treated with 3-MA $(1 \mathrm{mM})$ for $60 \mathrm{~min}$ followed by RAD or cilengitide $(10$ or $50 \mu \mathrm{M})$ for $48 \mathrm{~h}$. Metabolic activity was assessed by MTT assay and is indicated relative to RAD-treated cells 
a
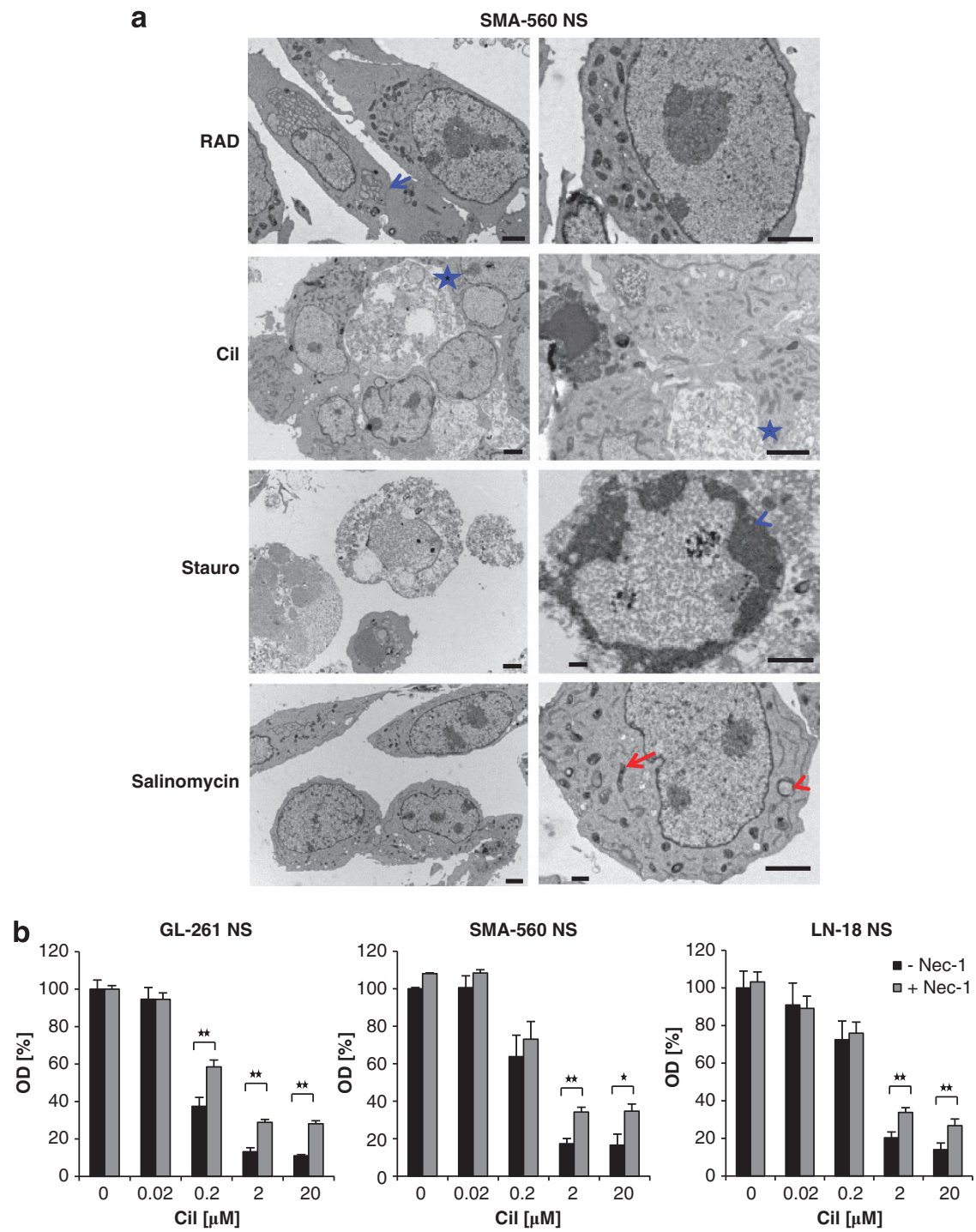

Figure 6 Cilengitide-treated mouse glioma NS cells undergo necrosis. (a) SMA-560 NS cells were exposed to RAD, cilengitide (10 $\mu \mathrm{M})$, staurosporine $(1 \mu \mathrm{M})$ or salinomycin $(5 \mu \mathrm{M})$ as indicated for $48 \mathrm{~h}$ and monitored by TEM. Images in the right column of each panel show a magnified part of the images on the left. Cells binding to each other are indicated with blue arrows, blue stars point to necrosis-like cell debris, blue arrowheads to crescent DNA along the nucleus, red arrows to swollen mitochondria and red arrowheads to autophagosomes (scale bar, $2 \mu \mathrm{m})$. (b) GL-261 or SMA-560 NS cells were treated with Nec-1 $(100 \mu \mathrm{M})$ for 60 min followed by increasing concentrations of cilengitide as indicated for $72 \mathrm{~h}$. Metabolic activity was assessed by MTT assay and is indicated relative to control cells not preexposed to Nec-1

cell death as well as to integrin control of the TGF- $\beta$ pathway. Elucidating why sphere cultures are resistant to integrin inhibition is an interesting question that is beyond the scope of the present work. Unpublished work from our laboratory shows that simply transferring mouse glioma cells into sphere cultures does not make these cells uniformly stem-like by current criteria of stemness (M Ahmad et al., submitted for publication).

Most cells undergo cell death upon integrin inhibitionmediated detachment, a process called anoikis. ${ }^{27,28}$ Anoikis has previously been described essentially as an apoptotic process. ${ }^{13}$ It has been reported that endothelial cells and human glioma cell lines undergo detachment and apoptosis upon integrin inhibition with Cil. ${ }^{25}$ However, upon integrin inhibition, we did not observe any signs of apoptosis. The cells neither displayed increased DEVD-amc-cleaving caspase activity nor increased caspase 3 processing. Furthermore, addition of the pan-caspase inhibitor ZVAD-fmk or expression of the caspase 1/8 inhibitor crm-A did not rescue integrin inhibition-induced cell death (Figure 4). Finally, electron microscopy ruled out necrosis as the principal mode of cell death after integrin inhibition (Figure 6a). The induction of necrosis involved necroptosis, the programmed form of necrosis (Figure 6b).

Autophagy has been proposed as a primary effector mechanism of anoikis, and autophagy may also represent an execution backup to apoptosis in apoptosis-resistant cells. ${ }^{29}$ Human glioma cells have been reported to undergo autophagy upon integrin inhibition with $\mathrm{Cil}$ at concentrations of $25 \mathrm{mg} / \mathrm{ml}$, corresponding to $44 \mu \mathrm{M}^{24}$ In our cell models, 

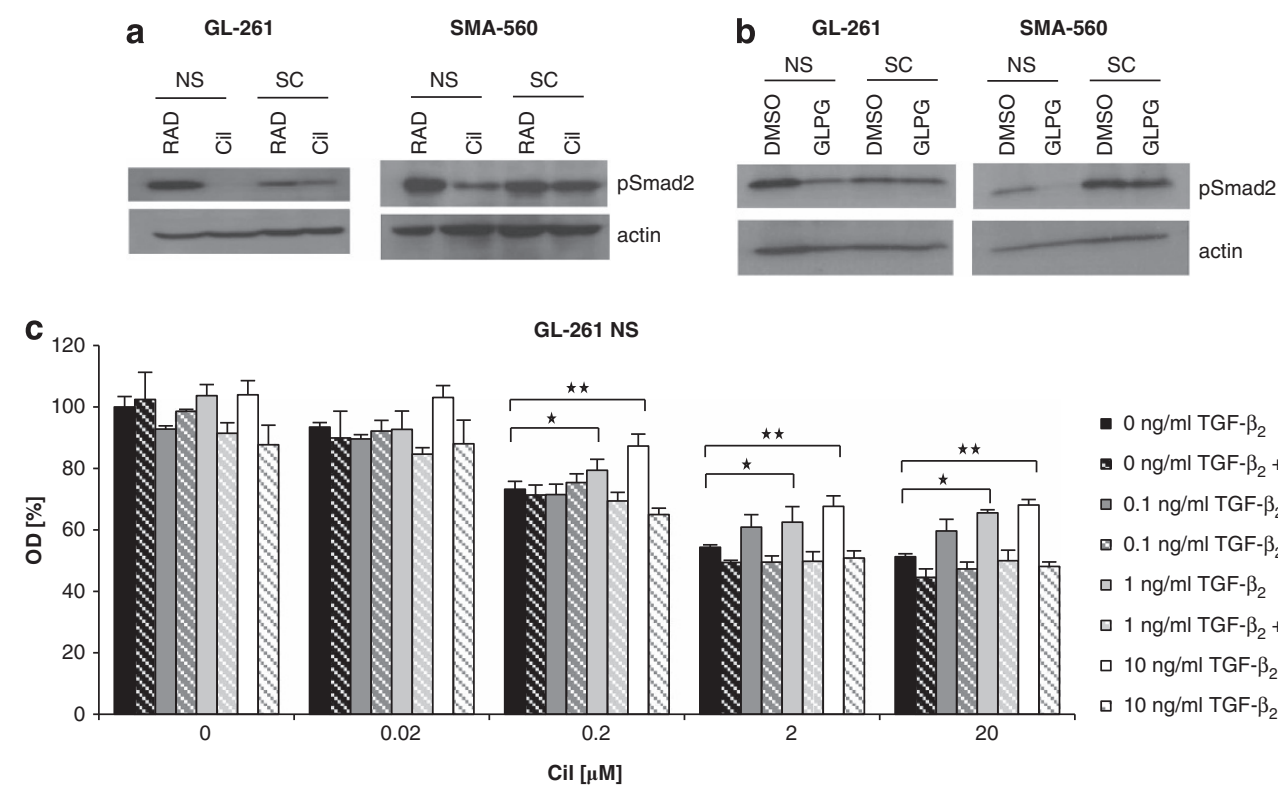

- $0 \mathrm{ng} / \mathrm{ml}$ TGF- $\beta_{2}$

v $0 \mathrm{ng} / \mathrm{ml}$ TGF $-\beta_{2}+$ SD-208

ㅁ $0.1 \mathrm{ng} / \mathrm{ml}$ TGF- $\beta_{2}$

๑ $0.1 \mathrm{ng} / \mathrm{ml}$ TGF- $\beta_{2}+\mathrm{SD}-208$

$1 \mathrm{ng} / \mathrm{ml}$ TGF $-\beta_{2}$

口 $1 \mathrm{ng} / \mathrm{ml}$ TGF $-\beta_{2}+$ SD-208

ㅁ $10 \mathrm{ng} / \mathrm{ml} \mathrm{TGF}-\beta_{2}$

口 $10 \mathrm{ng} / \mathrm{ml} \mathrm{TGF}-\beta_{2}+$ SD-208

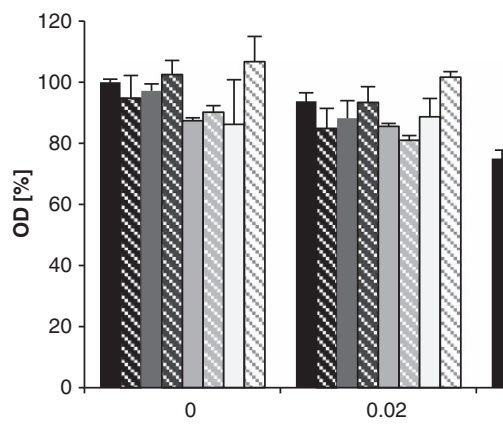

SMA-560 NS
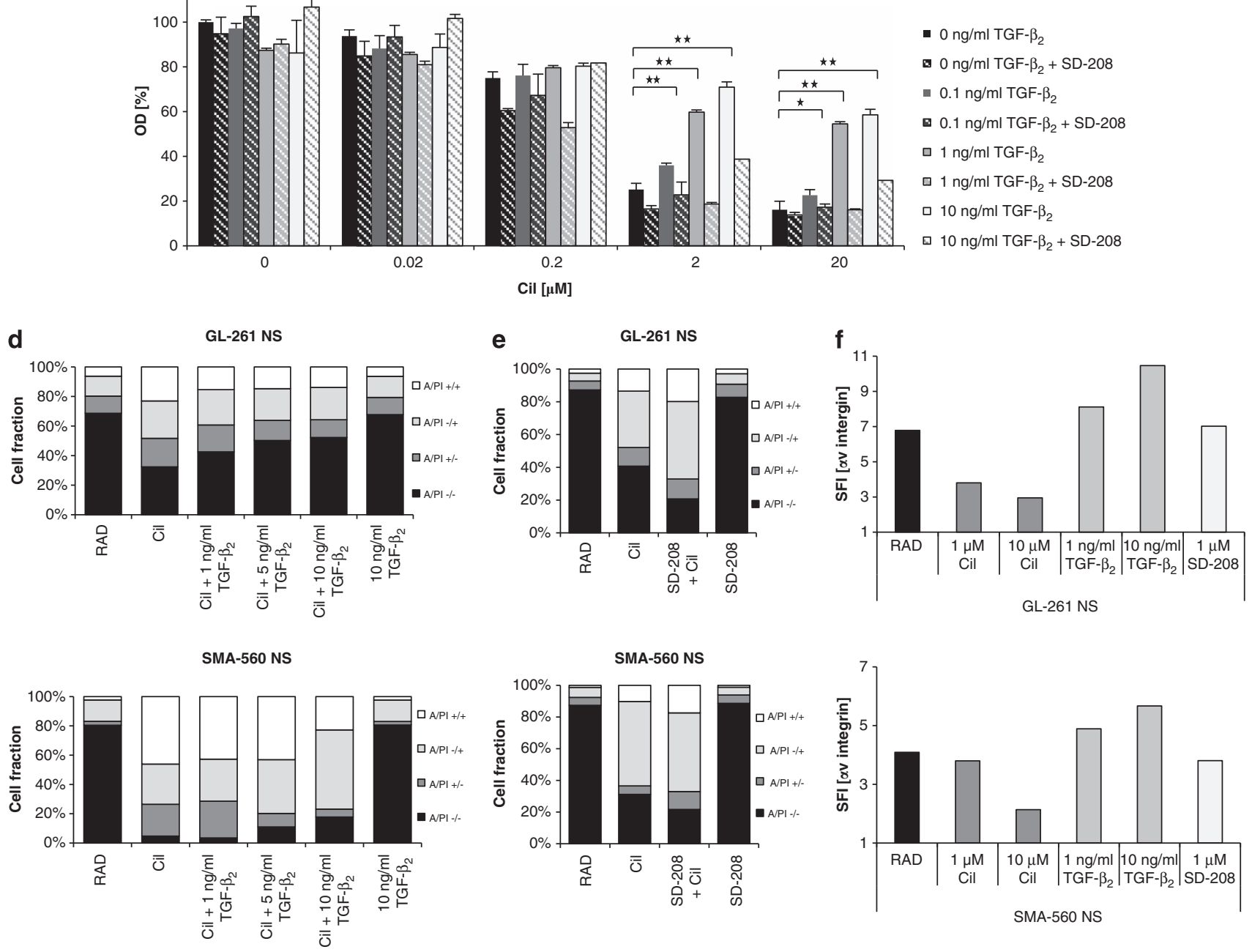
autophagy was inducible upon integrin inhibition with $50 \mu \mathrm{M}$ Cil. However, this is apparently not the mechanism responsible for cell death in these cells as a major loss of viability was observed with Cil concentrations as low as 100 nM (Figure 2); moreover, the inhibition of autophagy even increased the extent of cell death (Figure 5e). Accordingly, autophagy has been described as a prosurvival mechanism through suppression of necrotic cell death. ${ }^{30}$ Furthermore, it has been reported that autophagy may promote cell survival particularly in the context of anoikis. ${ }^{31,32}$

Recently, we have shown that inhibition of integrin signaling using various approaches reduces TGF- $\beta$ expression and TGF- $\beta$ signaling in human glioma cell lines. ${ }^{15}$ Thus, we were interested to explore whether this mechanism may be involved in detachment-induced cell death. Blocking integrin function with Cil or with GLPG0187 reduced TGF- $\beta$ signaling in adherent murine glioma cells, whereas no such effect became apparent in sphere cells (Figures $7 a$ and b). When adherent GL-261 and SMA-560 cells were cultured on plates coated with collagen, which is not a substrate for $\alpha \mathrm{v}$ integrins, pSmad2 reductions were observed upon integrin inhibition, even without detachment, but to a much lower extent than under conditions of detachment (Supplementary Figure 5). These data suggest that impaired TGF- $\beta$ signaling upon integrin inhibition results from both integrin inhibition and detachment. Indeed, because of very rapid detachment of adherent murine glioma cells upon integrin inhibition at lowest concentration, a separate analysis of attached and detached cell fractions was technically not possible. These data prompted us to investigate whether impaired TGF- $\beta$ signaling is linked to the induction of cell death in adherent cells upon integrin inhibition. Indeed, cell death was partially rescued by exogenous TGF- $\beta_{2}$ in a SD-208-sensitive manner (Figures 7c and d). Previously, exposure of human glioma cells to TGF- $\beta$ has been shown to induce integrin $\alpha \mathrm{v} \beta 3$ expression, an effect that was postulated to promote migration. ${ }^{19}$ Here, TGF- $\beta$ enhanced the survival of mouse glioma cells without promoting attachment, indicating that TGF- $\beta$ can promote survival downstream of integrin signaling under a stress condition such as anoikis. Integrin $\alpha \mathrm{v} \beta 3$ expression in carcinoma cells was linked to enhanced anchorage-independent tumor growth and to increased lymph node metastases by activation of c-Src and phosphorylation of Crk-associated substrate (CAS), resulting in tumor cell survival independent of cell adhesion. ${ }^{33}$ In addition, TGF- $\beta$ may induce the activation of prosurvival pathways such as $\mathrm{MAPK}^{34,35}$ and $\mathrm{PI} 3 \mathrm{~K}^{36}$ the pathways also implicated in adhesion-regulated cell survival. ${ }^{10}$ Our results may therefore point to a novel mode of anoikis in the absence of apoptosis, but related to necrosis and partially controlled by the TGF- $\beta$ pathway in glioma cells.

\section{Materials and Methods}

Cells and reagents. The human glioma cell line $L N-18$ was provided by $N$ de Tribolet (Lausanne, Switzerland). Mouse SMA-497, SMA-540 and SMA-560 glioma cells were provided by D Bigner (Durham, NC, USA) and GL-261 cells by XO Breakefield (Boston, MA, USA). The cells were cultured in Dulbecco's modified Eagle's medium (DMEM; Invitrogen, Basel, Switzerland) containing $2 \mathrm{mM}$ L-glutamine (Gibco Life Technologies, Paisley, UK) and 10\% fetal calf serum (FCS; PAA, Vienna, Austria) (standard conditions, NS) or in Neurobasal Medium with B-27 supplement $(20 \mu \mathrm{l} / \mathrm{ml})$ and Glutamax $(10 \mu \mathrm{l} / \mathrm{ml})$ from Invitrogen and fibroblast growth factor-2 (FGF-2), epidermal growth factor (EGF) $(20 \mathrm{ng} / \mathrm{ml}$ each; Peprotech, Rocky Hill, PA, USA) and heparin (32 IE $/ \mathrm{ml}$; Ratiopharm, Ulm, Germany) (sphere conditions, SC). Accutase was obtained from PAA. Cil (EMD 121974) was kindly provided by Merck KGaA (Darmstadt, Germany) and GLPG0187 was kindly supplied by Galapagos NV (Mechelen, Belgium). The RAD peptide cyclo-(Arg-Ala-Asp-DPhe-Val) was purchased from Bachem AG (Bubendorf, Switzerland). The following antibodies were used for immunoblot analysis: goat polyclonal antibody to actin and beclin-1 antibody were obtained from Santa Cruz Biotechnology (Santa Cruz, CA, USA), phospho-Smad2 antibody (Ser465/467) (clone 138D4), caspase-3 antibody and LC3A/B antibody were purchased from Cell Signaling Technology (Boston, MA, USA) and crm-A antibody from BD Biosciences (Franklin Lakes, NJ, USA). Recombinant human TGF- $\beta_{2}$ was purchased from PeproTech. The TGF- $\beta$ receptor I kinase inhibitor SD-208 was provided by Scios Inc. (Fremont, CA, USA). ZVAD-fmk was purchased from Tocris Bioscience (Bristol, UK), 3-MA from Sigma-Aldrich (St. Louis, MO, USA) and Nec-1 from Merck KGaA. MFL was provided by Topotarget (Copenhagen, Denmark). Staurosporine was from AppliChem (Darmstadt, Germany), annexin V from BD Biosciences and PI was from Sigma-Aldrich. Cell culture dishes coated with fibronectin (FN), laminin (Lam), collagen I (Col I) or collagen IV (Col IV) were purchased from BD Biosciences. Poly(2-hydroxyethyl methacrylate) (Poly-HEMA) was purchased from Sigma-Aldrich. The siRNA pool targeting integrin $\alpha \mathrm{V}(\mathrm{ON}-$ TARGETplus SMARTpool) and the nontargeting control pool (ON-TARGETplus siCONTROL) were purchased from Thermo Scientific Dharmacon (Lafayette, CO, USA) and used at $100 \mathrm{nM}$. The duplex sense sequences of the siRNA pool targeting $\alpha \mathrm{v}$ were: $5^{\prime}$-GCGCAAUCCUGUACGUGAA- $3^{\prime}, 5^{\prime}$-CCAAUUAGCAACAC GGACU- $3^{\prime}, 5^{\prime}$-GUGAGGAACUGGUCGCCUA-3' and $5^{\prime}$-GUGAACAGAUGGCUG CGUA-3'. Stable crm-A transfectants were obtained using the pEFR crm-A plasmid $^{37}$ and subsequent puromycin selection $(10 \mu \mathrm{g} / \mathrm{ml})$. Stable and transient lipophilic transfection was performed with Metafectene Pro (Biontex, Martinsried, Germany).

Real-time PCR. Total RNA was isolated using the NucleoSpin RNA II system from Macherey-Nagel (Düren, Germany) and CDNA was prepared using the iScript cDNA Synthesis Kit from Bio-Rad Laboratories AG (Cressier, France). For realtime PCR, gene expression was measured in an ABI Prism 7000 Sequence Detection System (Applied Biosystems, Foster City, CA, USA) with SYBR Green Master Mix (Thermo Fisher Scientific, Waltham, MA, USA) and primers (Microsynth AG, Balgach, Switzerland) at optimized concentrations. The sequences were as follows: glyceraldehyde 3-phosphate dehydrogenase (GAPDH), forward 5'-AGGTCGGTGTGAACGGATTTG-3' (NM_008084, 8-28 nt), reverse $5^{\prime}$-TGTAGACCATGTAGTTGAGGTCA-3' (NM_008084, 130-108 nt); $\alpha \mathrm{v}$, forward 5'-AAAGACCGTTGAGTATGCTCCA-3' (NM_008402, nt 492-513), reverse 5'-ATGCTGAATCCTCCTTGACAAAA- $3^{\prime}$ (NM_008402, nt 572-550); $\alpha 5$, forward 5'-CTTCTCCGTGGAGTTTTACCG-3' (NM_010577, nt 192-212), reverse 5'-GCTGTCAAATTGAATGGTGGTG-3' (NM_010577, nt 354-333); $\beta 1$, forward 5'-ATGCCAAATCTTGCGGAGAAT-3' (NM_010578, nt 92-112), reverse 5' - TTTG CTGCGATTGGTGACATT-3' (NM_010578, nt 300-280); $\beta 3$, forward 5'-GGCGTT GTTGTTGGAGAGTC-3' (NM_016780, nt 61-80), reverse 5'-CTTCAGGTTACATC GGGGTGA-3' (NM_016780, nt 198-178); $\beta 5$, forward 5'- GAAGTGCCACCTCGT GTGAA-3' (NM_001145884, nt 92-111), reverse 5'- GGACCGTGGATTGCCAAAGT-3'

Figure 7 TGF- $\beta_{2}$ counteracts integrin inhibition-induced cell death. (a) GL-261 (left) or SMA-560 (right) NS cells or SCs were exposed to RAD or cilengitide (10 $\mu$ M). (b) GL-261 (left) or SMA-560 (right) NS cells or SCs were exposed to DMSO or GLPG0187 (1 nM). Subsequently, whole-cell protein lysates were assessed for pSmad2 levels by immunoblot, using actin as a loading control. (c) GL-261 NS cells or SMA-560 NS cells were exposed to combinations of cilengitide and TGF- $\beta_{2}$ as indicated with or without SD-208 $(1 \mu \mathrm{M})$. Metabolic activity was assessed using MTT assay. (d) GL-261 NS cells or SMA-560 NS cells were exposed to RAD, cilengitide (10 $\mu \mathrm{M})$, TGF- $\beta_{2}(10 \mathrm{ng} / \mathrm{ml})$ or a combination of cilengitide $(10 \mu \mathrm{M})$ and increasing concentrations of TGF- $\beta_{2}$ as indicated for $48 \mathrm{~h}$. Viability was assessed by annexin V/PI staining. (e) GL-261 NS cells or SMA-560 NS cells were exposed to RAD, cilengitide $(10 \mu \mathrm{M})$, SD-208 $(1 \mu \mathrm{M})$ or a combination of cilengitide $(10 \mu \mathrm{M})$ and SD-208 $(1 \mu \mathrm{M})$ for $48 \mathrm{~h}$. Cell viability was assessed by annexin V/PI staining. (f) The $\alpha$ v protein levels were assessed by flow cytometry in GL-261 NS cells or SMA-560 NS cells exposed to RAD $(10 \mu \mathrm{M})$, cilengitide (1 or $10 \mu \mathrm{M})$, TGF- $\beta_{2}(1$ or $10 \mathrm{ng} / \mathrm{ml})$ or SD-208 $(1 \mu \mathrm{M})$ for $48 \mathrm{~h}$ 
(NM_001145884, nt 177-158); and $\beta 8$, forward 5'- TGGCCCTTTATTCCCGTGAC-3' (NM_177290, nt 530-549), reverse 5'-GGGTGGATACTAATGTATGG CGA-3' (NM_177290, nt 611-589). The conditions were 40 cycles at $95^{\circ} \mathrm{C} / 15 \mathrm{~s}$ and $60^{\circ} \mathrm{C} / 1 \mathrm{~min}$. Standard curves were generated for each gene. Relative quantification of gene expression was determined by comparison of threshold values. All results were normalized to GAPDH and calculated with the $\triangle \mathrm{CTT}$ method for relative quantification. ${ }^{38}$

Immunoblot analysis. For the detection of proteins from cell lysates, cells were lysed in radioimmunoprecipitation assay (RIPA) buffer (10 mM Tris, $\mathrm{pH} 8.0$, $150 \mathrm{mM} \mathrm{NaCl}, 1 \% \mathrm{NP}-40,0.5 \%$ deoxycholate, $0.1 \%$ sodium dodecyl sulfate) supplemented with $1 \times$ complete inhibitor mix (Roche Diagnostics, GrenzachWyhlen, Germany) and phosphatase inhibitor cocktails 1 and 2 (Sigma-Aldrich). Protein levels were analyzed by immunoblot using $20 \mu \mathrm{g}$ of protein per lane mixed with Laemmli buffer containing $\beta$-mercaptoethanol. Equal protein loading was ascertained by Ponceau $S$ staining. Visualization of protein bands was accomplished using horseradish peroxidase (HRP)-coupled secondary antibodies (Sigma-Aldrich) and enhanced chemiluminescence (Perbio, Bonn, Germany).

Flow cytometry. For detection of $\alpha v$ cell surface protein levels, cells were detached with accutase, incubated with primary antibody anti- $\alpha$ (Biolegend, San Diego, CA, USA) or isotype control, followed by exposure to fluorescein isothiocyanate (FITC)-conjugated secondary antibody anti-rat IgG conjugate (Sigma-Aldrich) and diluted in PBS containing $0.5 \%$ bovine serum albumin, $2 \mathrm{mM}$ EDTA and $1 \mathrm{mM} \mathrm{MgCl}$. For detection of intracellular $\alpha \mathrm{v}$ protein levels, cells were permeabilized using the Fix/Perm Buffer Set (Biolegend) before $\alpha$ v staining. Cell surface or intracellular expression levels were determined using a CyAn flow cytometer.

For the detection of AVOs, the cells were removed from the plate with accutase and stained with acridine orange (Sigma-Aldrich) at a final concentration of $1 \mu \mathrm{g} / \mathrm{ml}$. Green (510-530 nm, FITC) and red (>650 nm, phycoerythrin (PE)) excitation light was measured with a CyAn flow cytometer. ${ }^{39}$ For analysis of cell death, cells were treated as indicated, incubated with FITC-labeled AnxV-fluorescein isothiocyanate and $\mathrm{PI}$ for $20 \mathrm{~min}$ and fluorescence was recorded in a CyAn flow cytometer. AnxVfluorescein isothiocyanate- or PI-positive cells were counted as dead cells (either apoptotic or necrotic), and the remaining cells were designated the surviving cell fraction.

Caspase activity assay. Caspase activity was assessed using the fluorescent substrate DEVD-amc (Bachem AG) and a Mithras microplate reader (Berthold Technologies, Bad Wildbad, Germany). Cells were kept in phenol redfree medium containing the different compounds as indicated. ${ }^{40}$ Subsequently, cells were lysed and exposed to $12.5 \mu \mathrm{M}$ DEVD-amc for $1 \mathrm{~h}$.

MTT assay. For cytotoxicity assays, $10^{4}$ cells per well were seeded in 96-well plates, allowed to attach for $24 \mathrm{~h}$ and subsequently exposed to different compounds as indicated in a serum-free medium. For clonogenic assays, $10^{2}$ cells per well were seeded in 96-well plates, allowed to attach for $24 \mathrm{~h}$ and subsequently exposed to different compounds as indicated for $24 \mathrm{~h}$ in serum-free medium, followed by observation for 7-14 days in serum-containing medium. For both assays, metabolic activity as a surrogate marker of viability was assessed using MTT.

NHS-Biotin staining. Cells were detached using accutase, incubated with $0.1 \mathrm{mg} / \mathrm{ml} \mathrm{NHS}$-Biotin (Applichem) for $30 \mathrm{~min}$ on ice, fixed in PBS containing $3 \%$ paraformaldehyde and $2 \%$ sucrose and subsequently cytospun onto glass slides. For visualization, Cy3-conjugated streptavidin (Biolegend) was applied. Samples were mounted in Vectashield Mounting Media with DAPI (Burlingame, CA, USA).

MDC staining. Cells were detached using accutase, incubated with $50 \mu \mathrm{M}$ MDC (Sigma-Aldrich) for $10 \mathrm{~min}$ at $37^{\circ} \mathrm{C}$, fixed in PBS containing $2 \%$ paraformaldehyde, cytospun onto glass slides and analyzed by fluorescence microscopy. The presence of cells on the glass slides was approved by DAPI staining in parallel.

Transmission electron microscopy. Cells treated as indicated were fixed in $2.5 \%$ glutaraldehyde in $100 \mathrm{mM}$ sodium cacodylate buffer, $\mathrm{pH} 7.4$, dehydrated in a graded ethanol series after $\mathrm{OsO}_{4}$ fixation and embedded into epon (Catalyst). Sections of $60 \mathrm{~nm}$ were imaged with a Tecnai Spirit transmission electron microscope (FEI, Hillsborough, OR, USA).

Statistical analysis. Data are presented as means and S.D. The experiments shown were commonly repeated three times. Representative experiments are shown for some studies. Analysis of significance was performed using a two-tailed Student's t-test (Excel, Microsoft, Redmond, WA, USA) $\left({ }^{\star} P<0.05,{ }^{* *} P<0.01\right)$.

\section{Conflict of Interest}

$\mathrm{M}$ Weller and $\mathrm{P}$ Roth have received honoraria for advisory board activities for MSD and Roche. M Silginer and U Ziegler declare no conflict of interest.

Acknowledgements. This study was supported by Oncosuisse/Swiss Cancer League and an unrestricted grant from Merck Serono (Darmstadt, Germany). We thank Dr. S Goodman (Darmstadt, Germany) for valuable discussions.

1. Arnaout MA, Goodman SL, Xiong JP. Structure and mechanics of integrin-based cell adhesion. Curr Opin Cell Biol 2007; 19: 495-507.

2. Humphries JD, Byron A, Humphries MJ. Integrin ligands at a glance. J Cell Sci 2006; 119: 3901-3903.

3. Desgrosellier JS, Cheresh DA. Integrins in cancer: biological implications and therapeutic opportunities. Nat Rev Cancer 2010; 10: 9-22.

4. Mitra SK, Schlaepfer DD. Integrin-regulated FAK-Src signaling in normal and cancer cells. Curr Opin Cell Biol 2006; 18: 516-523.

5. Aoudjit F, Vuori K. Matrix attachment regulates Fas-induced apoptosis in endothelial cells: a role for C-flip and implications for anoikis. J Cell Biol 2001; 152: 633-643.

6. Courter DL, Lomas L, Scatena M, Giachelli CM. Src kinase activity is required for integrin alphaVbeta3-mediated activation of nuclear factor-kappaB. J Biol Chem 2005; 280: 12145-12151.

7. Alavi A, Hood JD, Frausto R, Stupack DG, Cheresh DA. Role of Raf in vascular protection from distinct apoptotic stimuli. Science 2003; 301: 94-96.

8. Matter ML, Ruoslahti E. A signaling pathway from the alpha5beta1 and alpha(v)beta3 integrins that elevates bcl-2 transcription. J Biol Chem 2001; 276: 27757-27763.

9. Aoudjit $F$, Vuori K. Integrin signaling inhibits paclitaxel-induced apoptosis in breast cancer cells. Oncogene 2001; 20: 4995-5004.

10. Reddig PJ, Juliano RL. Clinging to life: cell to matrix adhesion and cell survival. Cancer Metastasis Rev 2005; 24: 425-439.

11. Stupack DG, Puente XS, Boutsaboualoy S, Storgard CM, Cheresh DA. Apoptosis of adherent cells by recruitment of caspase-8 to unligated integrins. J Cell Biol 2001; 155: 459-470.

12. Stupack DG, Cheresh DA. Get a ligand, get a life: integrins, signaling and cell survival. J Cell Sci 2002; 115: 3729-3738.

13. Taddei ML, Giannoni E, Fiaschi T, Chiarugi P. Anoikis: an emerging hallmark in health and diseases. J Pathol 2012; 226: 380-393.

14. Deb M, Sengupta D, Patra SK. Integrin-epigenetics: a system with imperative impact on cancer. Cancer Metastasis Rev 2012; 31: 221-234.

15. Roth P, Silginer M, Goodman SL, Hasenbach K, Thies S, Maurer G et al. Integrin control of the transforming growth factor-beta pathway in glioblastoma. Brain 2013; 136: 564-576.

16. Bruna A, Darken RS, Rojo F, Ocana A, Penuelas S, Arias A et al. High TGFbeta-Smad activity confers poor prognosis in glioma patients and promotes cell proliferation depending on the methylation of the PDGF-B gene. Cancer Cell 2007; 11: 147-160.

17. Wick W, Naumann $U$, Weller $M$. Transforming growth factor-beta: a molecular target for the future therapy of glioblastoma. Curr Pharm Des 2006; 12: 341-349.

18. Wipff PJ, Hinz B. Integrins and the activation of latent transforming growth factor beta1 - an intimate relationship. Eur J Cell Biol 2008; 87: 601-615.

19. Platten M, Wick W, Wild-Bode C, Aulwurm S, Dichgans J, Weller M. Transforming growth factors beta(1) (TGF-beta(1)) and TGF-beta(2) promote glioma cell migration via upregulation of alpha(V)beta(3) integrin expression. Biochem Biophys Res Commun 2000; 268: 607-611.

20. Galli R, Binda E, Orfanelli U, Cipelletti B, Gritti A, De Vitis S et al. Isolation and characterization of tumorigenic, stem-like neural precursors from human glioblastoma. Cancer Res 2004; 64: 7011-7021.

21. Kondo T, Setoguchi T, Taga T. Persistence of a small subpopulation of cancer stem-like cells in the C6 glioma cell line. Proc Natl Acad Sci USA 2004; 101: 781-786.

22. Maurer GD, Tritschler I, Adams B, Tabatabai G, Wick W, Stupp R et al. Cilengitide modulates attachment and viability of human glioma cells, but not sensitivity to irradiation or temozolomide in vitro. Neuro Oncol 2009; 11: 747-756.

23. Goodman SL, Picard M. Integrins as therapeutic targets. Trends Pharmacol Sci 2012; 33: 405-412. 
24. Lomonaco SL, Finniss S, Xiang C, Lee HK, Jiang W, Lemke $N$ et al. Cilengitide induces autophagy-mediated cell death in glioma cells. Neuro Oncol 2011; 13: 857-865.

25. Oliveira-Ferrer L, Hauschild J, Fiedler W, Bokemeyer C, Nippgen J, Celik I et al. Cilengitide induces cellular detachment and apoptosis in endothelial and glioma cells mediated by inhibition of FAK/src/AKT pathway. J Exp Clin Cancer Res 2008; 27: 86.

26. Pellegatta S, Poliani PL, Corno D, Menghi F, Ghielmetti F, Suarez-Merino B et al. Neurospheres enriched in cancer stem-like cells are highly effective in eliciting a dendritic cell-mediated immune response against malignant gliomas. Cancer Res 2006; 66: 10247-10252.

27. Maubant S, Saint-Dizier D, Boutillon M, Perron-Sierra F, Casara PJ, Hickman JA et al. Blockade of alpha $v$ beta3 and alpha $v$ beta5 integrins by RGD mimetics induces anoikis and not integrin-mediated death in human endothelial cells. Blood 2006; 108 : 3035-3044.

28. Rennebeck G, Martelli M, Kyprianou N. Anoikis and survival connections in the tumor microenvironment: is there a role in prostate cancer metastasis? Cancer Res 2005; 65: 11230-11235.

29. Horbinski C, Mojesky C, Kyprianou N. Live free or die: tales of homeless (cells) in cancer Am J Pathol 2010; 177: 1044-1052.

30. Shen HM, Codogno P. Autophagy is a survival force via suppression of necrotic cell death Exp Cell Res 2012; 318: 1304-1308.

31. Jain MV, Paczulla AM, Klonisch T, Dimgba FN, Rao SB, Roberg K et al. Interconnections between apoptotic, autophagic and necrotic pathways: implications for cancer therapy development. J Cell Mol Med 2013; 17: 12-29.

32. Fung C, Lock R, Gao S, Salas E, Debnath J. Induction of autophagy during extracellular matrix detachment promotes cell survival. Mol Biol Cell 2008; 19: 797-806.
33. Desgrosellier JS, Barnes LA, Shields DJ, Huang M, Lau SK, Prevost N et al. An integrin alpha(v)beta(3)-c-Src oncogenic unit promotes anchorage-independence and tumor progression. Nat Med 2009; 15: 1163-1169.

34. Lee MK, Pardoux C, Hall MC, Lee PS, Warburton D, Qing J et al. TGF-beta activates Erk MAP kinase signalling through direct phosphorylation of ShcA. EMBO J 2007; 26: 3957-3967.

35. Massague J. TGFbeta in cancer. Cell 2008; 134: 215-230.

36. Massague J. TGFbeta signalling in context. Nat Rev Mol Cell Biol 2012; 13: 616-630.

37. Strasser A, Harris AW, Huang DC, Krammer PH, Cory S. Bcl-2 and Fas/APO-1 regulate distinct pathways to lymphocyte apoptosis. EMBO J 1995; 14: 6136-6147.

38. Roth P, Junker M, Tritschler I, Mittelbronn M, Dombrowski Y, Breit SN et al. GDF-15 contributes to proliferation and immune escape of malignant gliomas. Clin Cancer Res 2010; 16: 3851-3859.

39. Jiang H, White EJ, Conrad C, Gomez-Manzano C, Fueyo J. Autophagy pathways in glioblastoma. Methods Enzymol 2009; 453: 273-286.

40. Eisele G, Roth P, Hasenbach K, Aulwurm S, Wolpert F, Tabatabai G et al. AP0010, a synthetic hexameric CD95 ligand, induces human glioma cell death in vitro and in vivo. Neuro Oncol 2011; 13: 155-164.

(c) (3) $\odot$ Cell Death and Disease is an open-access journal BY ${ }_{\mathrm{NC}}$ po published by Nature Publishing Group. This work is licensed under a Creative Commons Attribution-NonCommercialNoDerivs 3.0 Unported License. To view a copy of this license, visit http://creativecommons.org/licenses/by-nc-nd/3.0/

Supplementary Information accompanies this paper on Cell Death and Disease website (http://www.nature.com/cddis) 